\title{
TTR
}

Traduction, terminologie, re?daction

\section{Word, Text, Translation. Liber Amicorum for Peter Newmark, Gunilla Anderman \& Margaret Rogers (eds), Multilingual Matters, Cleveden, Buffalo, Toronto, Sydney, 1999, 240 p.}

\section{Sarah Cummins}

Volume 13, numéro 2, 2e semestre 2000

Les Antilles en traduction

The Caribbean in Translation

URI : https://id.erudit.org/iderudit/037418ar

DOI : https://doi.org/10.7202/037418ar

Aller au sommaire du numéro

Éditeur(s)

Association canadienne de traductologie

ISSN

0835-8443 (imprimé)

1708-2188 (numérique)

Découvrir la revue

Citer ce compte rendu

Cummins, S. (2000). Compte rendu de [Word, Text, Translation. Liber Amicorum for Peter Newmark, Gunilla Anderman \& Margaret Rogers (eds), Multilingual Matters, Cleveden, Buffalo, Toronto, Sydney, 1999, 240 p.] TTR, 13(2), 245-250. https://doi.org/10.7202/037418ar d'utilisation que vous pouvez consulter en ligne.

https://apropos.erudit.org/fr/usagers/politique-dutilisation/ 


\title{
COMPTES RENDUS
}

\author{
Word, Text, Translation. Liber Amicorum for Peter Newmark, \\ Gunilla Anderman \& Margaret Rogers (eds), Multilingual \\ Matters, Cleveden, Buffalo, Toronto, Sydney, 1999, 240 p.
}

The inspiration behind Word, Text, Translation, a Liber Amicorum for Peter Newmark, is a good one. Newmark's own pronouncements on translation have been both categorical and contradictory, so a collection of articles reflecting his influence has a better than average chance of presenting stimulating research and diverse points of view. Another good idea was to have the contributors preface their papers with a citation from Newmark's writings. The quotation serves as a point of departure for the writer - and, happily for the reader, the departure from Newmark's premise or stance is sometimes quite radical.

The first of the book's 22 chapters is the Introduction by its two editors, Gunilla Anderman and Margaret Rogers. They explain the grouping of the articles, as suggested by the collection's title, into four sections - Word, Context, Text, and Beyond - and provide an excellent, detailed summary of each of the contributions. This concise but thorough description of the entire book is recommended both to those wishing an overview of the collection and to those seeking an abstract of an individual paper. The volume also contains an index.

The Introduction is followed by the mistitled and underedited Chapter 2, "An Interview with Peter Newmark" by Monica Pedrola. This summary of Newmark's life, career, and thinking is interspersed with a few, mostly banal, quotes taken from a series of interviews in 1997. The tone is at times reminiscent of an obituary written by a distant cousin hoping for a bequest: "Born in Czechoslovakia, Peter Newmark [...] remained, throughout his life deeply attached to his place of birth", we are told, with no evidence or illustration of this attachment or its influence. Each stage of Newmark's development is recounted with similar vague platitudes, only occasionally hinting at something deeper.

Part I, "Word" is, to my mind, the least interesting section of the book. Janet Fraser, in "The Translator and the Word: The Pros and Cons of Dictionaries in Translation", reports on an experiment involving rookie and veteran translators, with unsurprising results; the 
uncontrolled and undefined variable of "the better translators" correlates with similarly undefined better results. Gunilla Anderson's "On the Perils of Particle Translation" never clearly defines the particles in question, and is thus unable to explicitly identify the translation issues. As a result, the article does not go much beyond noticing a phenomenon in one language that has no single failproof equivalent in another.

Viggo Hjørnager Pedersen, in "Accuracy in Translation" looks at several translations of Beowulf (unfortunately not the recent one by Seamus Heaney) to illustrate the difficulties a literary translator faces. In a successful translation, there is both loss and gain, he notes, and literary translators should try to balance the competing demands of source and target text.

In "Friends, False Friends and Foes or Back to Basics in L1 to L2 Translation", John M. Dodds touches on the debates over literal versus non-literal translation. Armed with no clear definitions (what exactly does it mean to use the "same" word in the target text as that used in the source text?) and hampered by the absurdity of taking either stance literally, he winds up in the middle of a road leading nowhere in particular, advising, as Newmark has done, to be literal, except when it would be wrong to be literal.

Reiner Arntz's "Training Translators in a 'Third Language'A New Approach" is a breath of fresh air in this section. He describes the University of Hildesheim's innovative approach to training translators in a third language through explicitly contrastive teaching that builds on acquired knowledge and skills. The first of three modules develops reading skills in the third language; at later stages, active competence and translation competence are addressed, along with a linguistic study of the third language. The program is bound to be of great interest to speakers, translators, and teachers of less used languages.

Part 2, called "Context", begins with a brief article by Eugene Nida, "The Role of Contexts in Translating", which gives examples of the importance, when translating, of considering various types of context - from syntagmatic context to the audience for the finished work. 
Candace Séguinot's "Translation Theory, Translating Theory and the Sentence" proposes that the sentence is not "a complete thought" and does not even contain thought. Séguinot uses translation and the complexity of communication in general to show that context in the broadest sense is a huge contributing factor, and provides anecdotal evidence that translators appeal to various-sized units of translation perhaps they are not "units" at all?

Mary Snell-Hornby, in "The 'Ultimate Confort': Word, Text and the Translation of Tourist Brochures", trains her critical and analytical skills on several amateur translations of tourist brochures encountered on holiday. Finding them wanting, she demonstrates that she herself can do a much better job and advises tourist operators to hire competent translators.

"Translating Terms in Text: Holding on to Some Slippery Customers" by Margaret Rogers challenges the view that terms are context-independent, that if terms are defined accurately and used correctly, their translation is "a simple cross-linguistic substitution exercise". Rogers's meticulous case study of three related technical terms used in a handbook on braking systems and its translation shows that even when there are no referential or cultural differences, equivalent terms can still be "slippery customers" in the context of a text.

The third grouping of papers is called "Text". Albrecht Neubert's "Words and Texts - Which are Translated? A Study in Dialectics" opens with the argument that words have a special status in translation - they are "unique vehicles of meaning". Sometimes they "leave indelible marks that resist easy rendering into words of another language", but at other times, they may serve as "vessels of thought that can shed their meaning neatly into new containers" (p. 120). Readers may feel they have wandered into a dye-works. Turning to aphorisms, Neubert tries to identify the characteristics that make the translation of their words fairly straightforward: aphorisms have general validity, the words reflect prototypical dictionary definitions, there is minimal contextuality. However, when words escape from paradigmatic meaning into syntagmatic and text meaning, translators must take both lexical and textual systems into account. Neubert illustrates this by a discussion of the use of the word slippage in Updike's short story of the same name. Having established a 
dichotomy, he concludes that it is perhaps a moot point to decide which strategies should dominate.

The title of Jan Firbas's contribution, "Translating the Introductory Paragraph of Boris Pasternak's Doctor Zhivago: A Case Study in Functional Sentence Perspective", is wholly self-explanatory. After analysing the Russian original in terms of functional sentence perspective - how linguistic elements combine to assign thematic/rhematic roles, set context and context-dependent elements, and identify the high point of a sentence - Firbas examines a Dutch, a German, an English, and a French translation to evaluate to what extent these elements are captured. This is a complex, illuminating analysis that shows how important these non-lexical elements are in a text and its translation.

David Connolly, in "Translating Prismatic Poetry: Odysseus Elytis and The Oxopetra Elegies", presents prismatic poetry, characterized by its "nuclei of self-generating radiance", and his own and the poet's views of whether and how it can be translated. Elytis and Connolly set the bar impossibly high: they seem to be talking not about translation but replication. Connolly claims prismatic poetry needs a unique approach, but the approach he takes is not unique. However, his analysis of the poetry and discussion of the factors taken into account are both subtle and sound, and the results - the translations - are fine.

Gideon Toury, in "How Come the Translation of a Limerick Can Have Four Lines (or Can It)?" takes the possibility questioned in the title as a springboard for a theoretical examination of translation in general and literary translation in particular. Literary texts present a bundle of literary features, qualitites, and aspects; by recognizing that not all can be translated simultaneously, we are led to make choices. With cogent argumentation, Toury shows why certain choices might be made and what their consequences might be. The strong theoretical basis and the rigour of Toury's argumentation make this article a standout.

"The Source Text in Translation Assessment", by Gerard McAlester, establishes distinctions among evaluation, criticism, analysis, all of which together make up "assessment" of a translation. McAlester reviews the assessment literature and encourages assessors to think more deeply about the type of assessment to be done, with due 
consideration of the demands of end user in addition to a critical comparison of source and target texts.

The book's final section, called "And Beyond", is a mixed bag. Hans Lindquist's "Electronic Corpora as Tools for Translation" is an interesting, detailed look at some of the uses translators can make of various electronic tools. Lindquist suggests that electronic corpora may turn out to be more useful than machine translation.

Sylfest Lomheim's "The Writing on the Screen. Subtitling: A Case Study from Norwegian Broadcasting (NRK), Oslo" is pioneering work in this specialized field. Lomheim illustrates various approaches to subtitling used in three different shows. He comes up with ten subtitling "strategies" that take into account the demands of the genre, and sets forth a model for subtitling.

In "Translating for Children", Eithne O'Connell argues that greater attention must be paid to this type of literary translation.

The title of Piotr Kuhiwczak's "Translation and Language Games in the Balkans" might be misleading to some: it is not about punning or puzzles, pig Latin or verlan. Instead, it illustrates how translation in "the former Yugoslavia" is being used, not to bridge gaps or encourage sharing and mutual understanding, but as a tool to create further distinctions and divisions.

Patrick Chaffey, in "ADNOM - A Project that Faded Away", tells the sad tale of a project to standardize a certain governmental nomenclature. He analyses this entirely worthwhile project and the reasons for its demise.

Last, Simon S. C. Chau's "From Anonymous Parasites to Transformation Agents - A 'Third World' Vision of Translation for the New Millennium" reminds readers that, beyond the sometimes rarefied discussions of the possible ways to translate advertisements or limericks or poetry, there is another world for which translation has a more down-to-earth significance. As Chau writes, "what gets translated, and how" charts the future of third-world societies.

This collection of essays, dealing with diverse topics from a range of perspectives, is a fitting gesture of friendship - and scholarly 
solidarity - to Peter Newmark and a recognition of his significant contributions to the study of translation.

Sarah Cummins Université Laval 